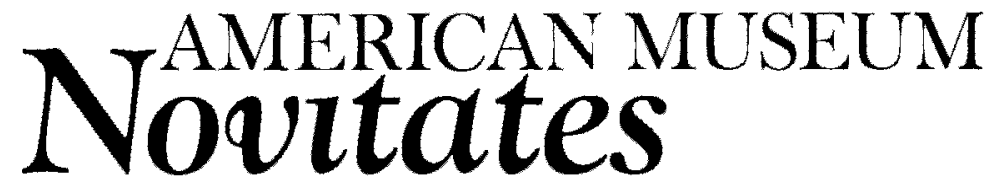

PUBLISHED BY THE AMERICAN MUSEUM OF NATURAL HISTORY CENTRAL PARK WEST AT 79TH STREET, NEW YORK, NY 10024 Number 3534, 11 pp., 15 figures

\title{
A New Eustenogater Species (Hymenoptera: Vespidae; Stenogastrinae), the First Hover Wasp Known to Overwinter on the Nest
}

\author{
FUKI SAITO ${ }^{1}$ LIEN P. T. NGUYEN, ${ }^{2}$ JAMES M. CARPENTER, ${ }^{3}$ AND \\ JUN-ICHI KOJIMA ${ }^{1,4}$
}

\begin{abstract}
A new species of hover wasp, Eustenogaster nigra Saito and Nguyen, is described based on females and males collected mainly in northern Viet Nam. The wasp is also distributed in mountainous areas of central Viet Nam and the southern part of China. All distribution records are from areas with more-or-less distinct seasons in terms of temperature. The nest is described and compared with those of other Eustenogaster species. A nest collected during early spring in Tam Dao National Park in northern Viet Nam, where there is a more-or-less distinct "winter", had five males and six virgin females, suggesting that both sexes overwinter on their nest.
\end{abstract}

\section{INTRODUCTION}

Not only because the hover wasps, Stenogastrinae, exhibit considerable diversity in social life and nesting behavior (reviewed in Turillazzi, 1991), but also the group is the basal clade of the social wasps (Carpenter, 1991), the subfamily is the key group for understanding of social evolution in the wasps. Little progress in the taxonomy of the
Stenogastrinae, however, has been made since Carpenter and Kojima (1997) pointed out that the stenogastrine taxonomy had not been well studied compared to the other two social wasp subfamilies, Vespinae and Polistinae.

Seven genera are currently recognized in the subfamily (Carpenter, 2001), and the late J. van der Vecht had been preparing taxonomic revisions of all the genera of the

\footnotetext{
${ }^{1}$ Natural History Laboratory, Faculty of Science, Ibaraki University, Mito, 310-8512 Japan (F.S., nd5507t@mcs. ibaraki.ac.jp; J.K., jkrte@mx.ibaraki.ac.jp).

${ }^{2}$ Insect Ecology Department, Institute of Ecology and Biological Resources, Vietnamese Academy of Science and Technology, 18 Hoang Quoc Viet Road, Nghia Do, Cau Giay, Ha Noi, Viet Nam (phuonglientit@yahoo.com).

${ }^{3}$ Division of Invertebrate Zoology, American Museum of Natural History, (carpente@amnh.org).

${ }^{4}$ Division of Invertebrate Zoology, American Museum of Natural History.
} 
Stenogastrinae; however, he died in 1992 before having completed the revisions of Eustenogaster van der Vecht, 1969, Liostenogaster van der Vecht, 1969, and Parischnogaster von Schulthess, 1914. The revisions of these genera that van der Vecht began were taken over by C.K. Starr on Parischnogaster and by $\mathrm{S}$. Turillazzi on Liostenogaster, but descriptions of only Liostenogaster species have appeared (Turillazzi, 1988, 1999; Turillazzi and Carfi, 1996).

The late van der Vecht distributed specimens of social wasps labeled with his manuscript names to various collections, and this was also the case for the Stenogastrinae. A regrettable consequence of this is that some of these names have been published as nomina nuda, including one name of Ropalidia Guérin-Méneville, 1831 (subfamily Polistinae) and two Liostenogaster names (Carpenter, 1982; Hansell, 1987a). The Ropalidia name has been validated (Kojima, 1989) and the two Liostenogaster species were subsequently described under different names (Turillazzi, 1988, 1999; see also Kojima, 2006).

Recently, one of van der Vecht's manuscript names in Eustenogaster was published as a nomen nudum. Nguyen and Khuat (2004) published the name in quotation marks, with a note that it came from van der Vecht's unpublished notes, and they gave its diagnostic characters in a key, together with a figure of the head in frontal view and a list of specimens examined. There was no intention to make the name available, as it is not under the current International Code of Zoological Nomenclature (ICZN, 1999). That is, Nguyen and Khuat (2004) neither made an explicit statement that the name is new (article 16) nor fixed the name-bearing type (article 16.4). In the present paper, we validate the name.

Eustenogaster is distributed from India to Southeast Asia, mainly in tropical areas. The nesting biology has been described for several species (Williams, 1919; von Schulthess, 1927; Bell, 1936; Pagden, 1958; Sakagami and Yoshikawa, 1968; Yoshikawa et al., 1969; Krombein, 1976; Ohgushi and Yamane, 1983; Ohgushi et al., 1983, 1986, 1988, 1990; Hansell, 1987b; Turillazzi, 1991; Francescato et al., 2002). In the present paper, we also describe the nests and some biological aspects of this new Eustenogaster species in Tam Dao National Park, in the northern part of Viet Nam, where social wasps in general appear to have a winter resting period.

\section{MATERIALS AND METHODS}

Most of the Vietnamese specimens were collected by ourselves and are deposited in the Institute of Ecology and Biological Resources, Hanoi, Viet Nam (IEBR), and as long-term loans in the American Museum of Natural History (AMNH) and the Natural History Collection, Ibaraki University, Mito, Japan (IUNH). Some specimens that we did not collect are also in the IEBR.

Morphological as well as color characters of adult wasps were observed on pinned-anddried specimens under a stereoscopic dissecting microscope. Male genitalia were dissected out, briefly cleared in $10 \% \mathrm{KOH}$, and observed in glycerin under a stereoscopic dissecting microscope. Nest measurements were made with digital calipers for envelope and cell sizes and with a micrometer for the cell wall thickness.

Abbreviations other than museum/institutional acronyms are as follows: F.S., Fuki Saito; ISD-c, collectors of the Insect Systematic Department of the IEBR; J.K., Jun-ichi Kojima; J.M.C., James M. Carpenter; NP, National Park; N.L., Lien Thi Phuong Nguyen.

\section{DESCRIPTION OF NEW SPECIES}

\section{Eustenogaster nigra Saito and Nguyen, new species}

Eustenogaster scitula (Bingham, 1897): Nguyen and Khuat, 2003: 696 [misidentification, partly].

Eustenogaster nigra: Nguyen and Khuat, 2004: 38, 40. Nomen nudum.

Female: Body length (head + mesosoma + first two terga) $19.5-21.5 \mathrm{~mm}$ (holotype: $19.5 \mathrm{~mm}$ ); forewing length $14.0-15.2 \mathrm{~mm}$ (holotype: $15.2 \mathrm{~mm}$ ). Head in frontal view (fig. 1) broad, about 1.1 times wider than high. Eyes enlarged, in lateral view strongly swollen at least in ventral half (fig. 2), maximum width about 4.5 times as wide as that of gena. 
Clypeus convex, with apex sharply pointed triangular; supraclypeal area irregularly punctuate, with small impunctate, flat area below anterior ocellus. Anterior ocellus slightly elliptical in shape $(0.32-0.36 \mathrm{~mm}$ wide, $0.28-$ $0.30 \mathrm{~mm}$ long), about 1.4 times larger in diameter than more-or-less circular posterior ocelli (diameter $0.22-0.26 \mathrm{~mm}$ ); distance between inner eye margin and posterior ocelli as long as width of anterior ocellus; ocelli close to each other (fig. 3); distance between anterior and posterior ocelli shorter than diameter of posterior ocellus; posterior ocelli separated from each other by about distance equal to their diameter. Mandible with three teeth; proximal tooth small, sharply pointed; middle and distal teeth extended, bluntly projected.

Scutum finely, densely punctate (interspaces smaller than punctures), with median carina developed anteriorly. Scutellum hairy, densely punctate, strongly convex medially, separated from metanotum by deep but narrow furrow. Metanotum rather strongly convex, hairy, rugosely punctate in posterior margin. Mesepisternum densely punctate at least in dorsal half. Propodeum hairy, with shallow, small punctures.

First metasomal tergum $8.0-8.6 \mathrm{~mm}$ long, about 6.1 times as long as maximum width, and 7.2 times longer than height; second tergum strongly convex dorsally (fig. 4); sixth tergum with a small tubercle (fig. 7).

Color: Body black; head with no spots or markings; paired short lines along posterodorsal margin of pronotum, and scrobal spot and spot below it (both often reduced) on mesepisternum yellow; posterior two-thirds of first tergum dark reddish brown; third tergum anterolaterally with paired, short, yellow lines. Legs dark brown to black; femora pale brown apically. Wings semihyaline, pale brown, darker along anterior margin of forewing; veins brown.

MALE: Body length (head + mesosoma + first two terga) $18-20 \mathrm{~mm}$; forewing length 14.5-15.5 mm. Structure and coloration similar to female, but clypeus less convex and with apex bluntly angled, sometimes with a median yellow mark of variable size; mandibular teeth rounded apically (fig. 8); second tergum less strongly convex dorsally (fig. 5); terga with no tubercle.
Genitalia: Parameral spines not dilated, with distinct depression at the base (fig. 9). Volsella bent at anterior margin, with digitus beak-shaped (fig. 10). Aedeagus slender, in lateral view slightly dilated apically (fig. 11), with a pair of projections located laterobasally (fig. 12).

Type Material: Holotype $q$ labeled "Viet Nam: Tam Dao (outside town), ca. $900 \mathrm{~m}$, Vinh Phuc, 7.iii.2005, L.T.P. Nguyen, F. Saito \& J. Kojima, Nest \#VNM-S2005B" and "No. 8", in IEBR; on long-term loan to IUNH.

Paratypes (unless the depository is mentioned, the paratypes are tentatively in IUNH on long-term loan from IEBR): CHINA: $2 \hat{\delta}$ (AMNH), Yen-ping [= Nanping or Yanping], [1 $\hat{\delta}, 31 . v i i i .1917 ; 1 \hat{\delta}$, 9.vi.1917]. VIET NAM: Thai Nguyen Province: $1+$, Cat Ne, Dai Tu, 23.x.2004, ISD-c; 11 $\delta$, Than Xa, Vo Nhai, ISD-c [7 $\delta, 470 \mathrm{~m}, 16 . x .2004 ; 2 \hat{\delta}, 90 \mathrm{~m}$, 19.x.2004; 2 ô, 70 m, 17.x.2004]; Phu Tho Province: $32 \hat{\delta}$, Xuan Son NP, N.L. [6ㅎ, $400 \mathrm{~m}, 11-$ 16.vi.2004; $8 \hat{\delta}, 500 \mathrm{~m}, 12 . v i .2004 ; 18 \hat{\delta}, 600 \mathrm{~m}$, 13.vi.2004]; Vinh Phuc Province: 5ㅇ, $21 \hat{\delta}$, Tam Dao NP [1 $\hat{\delta}, 800$ m, 7.ix.2000, N.L.; $1 \hat{\delta}, 1000$ m, 08.ix.2000, N.L.; $1 \hat{\delta}, 800$ m, 12.v.2003, N.L.; $13 \hat{\delta}$, $800 \mathrm{~m}, 01-04 . v i i .2003$, N.L.; $59,5 \hat{\jmath}$, same data as holotype; $5 \hat{\delta}$ (IEBR), 500-700 m, 20.viii.2005, J.K.]; 18, Ngoc Thanh, Me Linh, $100 \mathrm{~m}$, 24.v.2000, N.L.; 1 ㅇ, $1 \delta$, Ngoc Thanh, Me Linh, 22.viii.2000, X.L. Truong; $3 \hat{\delta}$, Tay Thien Mt., 26.viii.2004, N.L.; Ha Tay Province: $19,13 \hat{\delta}$, Ba Vi NP, N.L. [12 $\delta, 1+$, 800 m, 18.ix.2000; $1 \hat{\delta}, 400$ $600 \mathrm{~m}, 02 . v i .2001]$; $3 \hat{\delta}$, Yen Bai, Ba Vi, $>100 \mathrm{~m}$, 01.vi.2001, N.L.; Hai Phong Province: $5 \hat{\delta}$, Cat Ba NP, 15-18.vii.2003, N.L.; Hoa Binh Province: $1 \hat{\delta}$, $\mathrm{Pa}$ Co, Mai Chau, 1100 m, 23.iv.2002, V.T. Hoang; Nghe An Province: 38े, Chau Cuong, Quy Hop, X.H. Le [2 $\delta$, 17.vii.2004; $1 \hat{\delta}, 14 . v i i .2004] ; 1$ ㅇ, $1 \hat{\delta}$, Mon Son, Con Cuong, 22-24.vii.2004, N.L.; Ha Tinh Province: 1 f , 1 क (AMNH), 17 km SE, Huong Son, $18^{\circ} 22^{\prime} \mathrm{N}, 105^{\circ} 13^{\prime} \mathrm{E}, 180 \mathrm{~m}, 19-23.1 v .1998$, JMC; 1 के (AMNH), Huong Son, 200-300 m, $18^{\circ} 21^{\prime} \mathrm{N}, \quad 106^{\circ} 15^{\prime} \mathrm{E}, \quad 4 . v .1998$, J.M.C., Long, Grimaldi, Herman, and Silva; $1 \stackrel{\uparrow}{ }, 4 \hat{\delta}$, Son Hong, Huong Son, 25.iv.2004, X.L. Truong.

Other Specimens Examined: VIET NAM: Lang Son Province: 2ई, Bac Son, 01.vii.2003, X.L. Truong; Vinh Phuc Province: $2 \hat{\delta}$, Tam Dao NP, 800 m, 01-04.vii.2003, N.L.; Hoa Binh Province: 1 के, Lac Thinh, Yen Thuy, 30.iv.2002, D.L. Khuat; $1 \delta$, $\mathrm{Pa}$ Co, Mai Chau, 1100 m, 24.iv.2002, D.L. Khuat; $3 \hat{f}$, Da Phuc, Yen Thuy, 3.v.2002, V.T. Hoang; $1 \hat{\delta}$, Pa Co, Mai Chau, $>1100$ m, 21-23.x.2002, D.L. Khuat; Ninh Binh Province: $3 \hat{\delta}$, Cuc Phuong NP, Nho Quan, 7.v.2002, V.T. Hoang; $9 \hat{\delta}$, Cuc Phuong NP, Nho Quan, 08.v.2002, V.T. Hoang. 

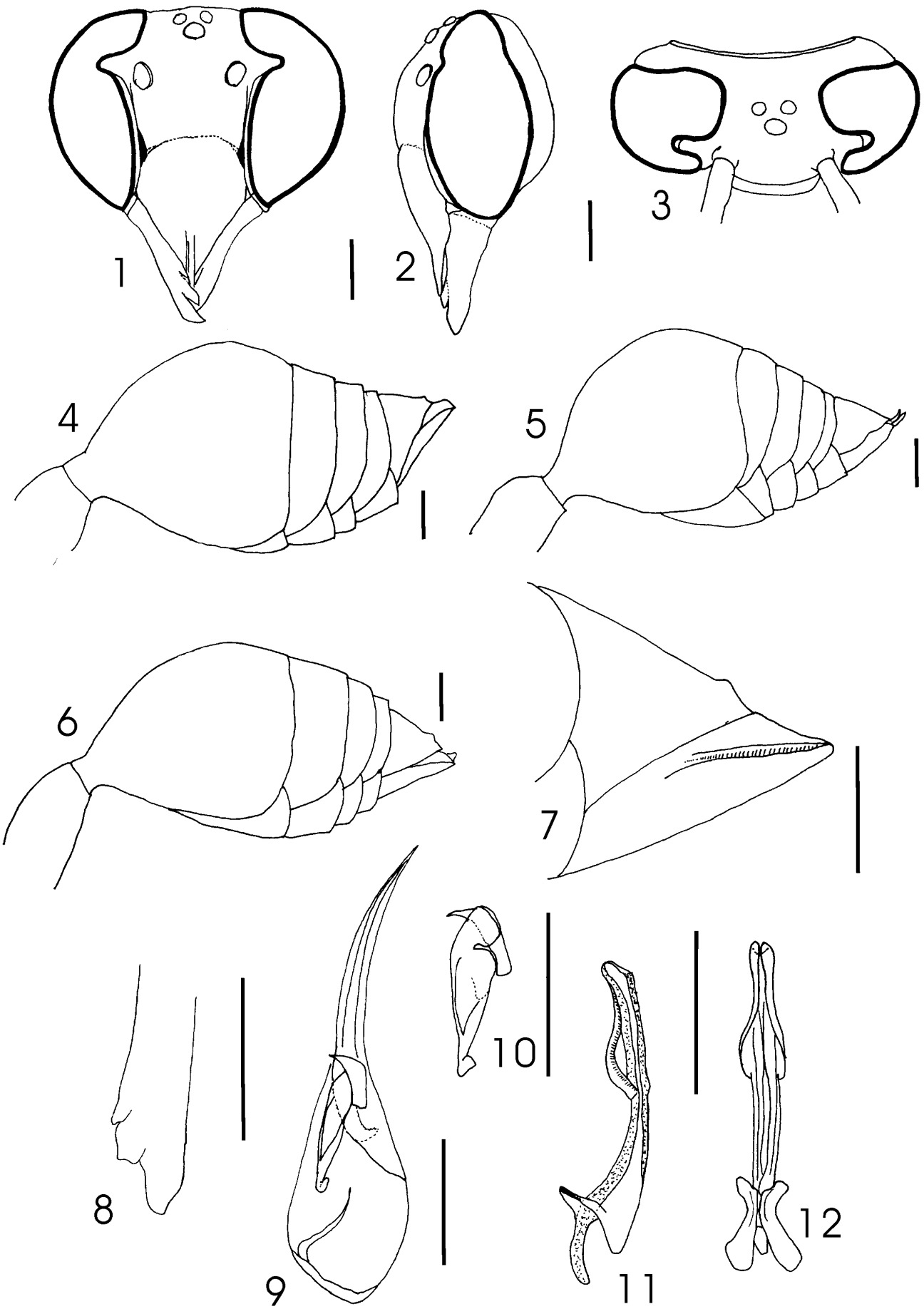

Figs. 1-12. Eustenogaster nigra holotype and paratypes. Scale bars are $1 \mathrm{~mm}$. 1-3. Eustenogaster nigra Saito and Nguyen, n.sp., female holotype. Head. 1. Frontal view. 2. Lateral view. 3. Dorsal view. 4-6. Second metasomal tergum in lateral view. 4. Eustenogaster nigra Saito and Nguyen, n.sp., female. 5. E. nigra, male. 6. E. scitula, female. 7. Eustenogaster nigra Saito and Nguyen, n.sp., female paratype. Sixth metasomal 
ETYMOLOGY: The specific name is the feminine of the Latin word niger, referring to nearly entirely black body of this species.

Remarks: This species is most similar to E. scitula, but the second metasomal tergum is more strongly convex (figs. 4-6) and the female mesoscutum is less convex than in $E$. scitula; furthermore, E. nigra is also easily distinguished from E. scitula by the lack of bright spots on the clypeus, upper part of the mesopleuron, scutellum, metanotum, and propodeum.

The specific name nigra is van der Vecht's manuscript name. van der Vecht undoubtedly distributed to various institutions/museums the specimens with type labels on which the name appears. We have not yet located the specimen with his holotype label.

Description of Nests: Two nests were collected in Tam Dao, northern Viet Nam, on 9 March 2005. One of them (nest A, fig. 13) was about $2.5 \mathrm{~m}$ from the ground, at the junction of two thin $(0.5-0.8 \mathrm{~mm}$ thick) wires hanging from the eaves of a house; the main substrate wire penetrates the basal part of the nest, with a free end hanging beyond the nest; the other wire is tied to the main wire, without a free hanging part. As in all known Eustenogaster species, the nest has an inverted-flask-shaped envelope. As in all species except E. calyptodoma, the envelope is made by extending the outer walls of peripheral cells, and thus its basal portion is comprised of the outer walls of peripheral cells. The apical, tubular part of the envelope is about $40 \mathrm{~mm}$ long and about $10 \mathrm{~mm}$ in diameter and is mesh-walled, with a broad horizontal flange near the apex. The upper part of the envelope is ornamented with three "wings" that project outward, two of which are closer to each other than to the last. The outer surface of the envelope is furnished with several keels, which run down continuously, slightly spirally, to the apical flange. The color of the nest is basically brown, with transverse stripes $(0.5-1.3 \mathrm{~mm}$ wide) of lighter and darker brown between the keels, indicating different sources of nest material. The comb consists of 19 cells, which are hexagonal in cross section. The cells in the central part of the comb are $6-7 \mathrm{~mm}$ in diameter (= side-to-side distance) at opening and $13-17 \mathrm{~mm}$ long; peripheral cells are somewhat larger (7-8 $\mathrm{mm}$ in diameter) and shorter (9-14 $\mathrm{mm}$ in length). The thickness of the cell walls is $0.24 \mathrm{~mm}$ on average $(0.12$ $0.38 \mathrm{~mm}, \mathrm{~N}=10)$. The nest carton is brittle, made from small chips mixed with a small amount of (possibly salivary) secretion. The part of the main substrate wire hung from the eaves is thinly covered with a single layer of carton sheet for about $70 \mathrm{~mm}$ from the base of the nest. The other substrate wire tied to the main wire is also covered by a carton sheet; the covering starts about $10 \mathrm{~mm}$ from the nest base and extends for about $100 \mathrm{~mm}$ toward the eaves; the part near the nest is tubelike (about $50 \mathrm{~mm}$ long and about $4 \mathrm{~mm}$ in diameter), and the both ends taper and are closed but it also has an irregularly shaped hole made by incomplete enclosure near the midlength.

The other nest (nest B, fig. 14) was attached to a thin (1.5-1.8 $\mathrm{mm}$ thick) twig protruding from a concrete basement, at about $2 \mathrm{~m}$ from the ground. The nest structure is basically the same as nest A, but the envelope might not have been completed and almost lacks in an apical tubular extension; the cells are very shallow (3-7 mm long), possibly due to the cell wall having been shaved off at adult emergence. The nest color is lighter than in nest $\mathrm{A}$, with the stripes in the envelope varying from pale brown to dark grayish brown. There are 15 cells. Mean thickness of cell walls is $0.43 \mathrm{~mm}(0.13-0.72 \mathrm{~mm}, \mathrm{~N}=10)$.

Wasps in the Nests: Nest A had four dead pupae in the central cells and no adults and no live brood. Two of the four dead pupae were so badly molded that we were unable to identify their sexes; the other two were a male and a female.

tergum in lateral view. 8. Eustenogaster nigra Saito and Nguyen, n.sp., male mandible. 9-12. Eustenogaster nigra Saito and Nguyen, n.sp., male paratype, genitalia. 9. Paramere and volsella in interior lateral view. 10. Volsella in interior lateral view. 11. Aedeagus in lateral view. 12. Aedeagus in ventral view. 

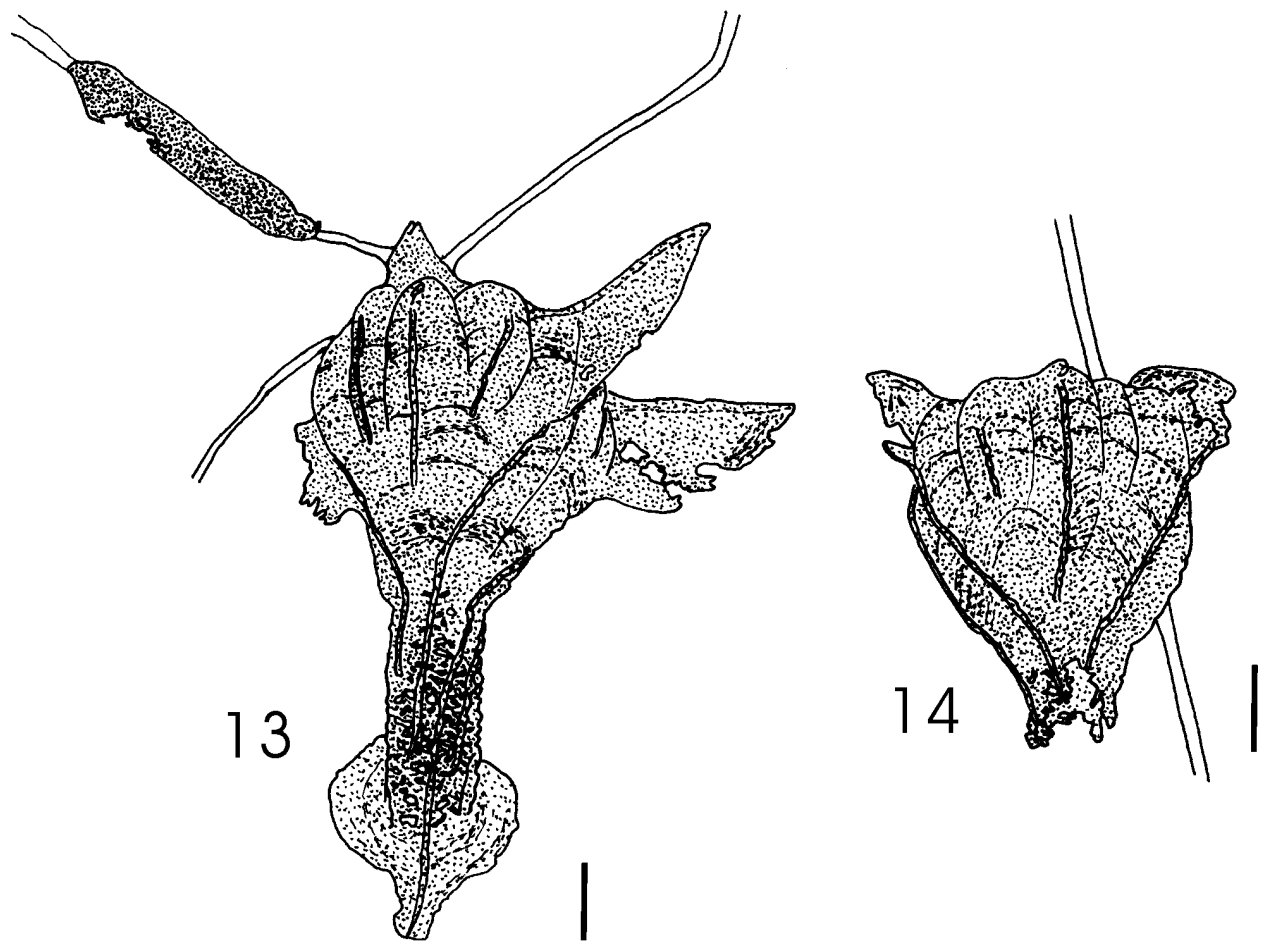

Figs. 13, 14. Nests of Eustenogaster nigra Saito and Nguyen, n.sp., collected in Tam Dao, northern Viet Nam, on 9 March 2005. 13. Nest A. 14. Nest B. Scale bars are $10 \mathrm{~mm}$.

In nest $\mathrm{B}, 11$ adult wasps (6 females and 5 males) and no immatures (pupae, larvae, or eggs) were present. When we collected the nest into a plastic bag, we treated it rather roughly, but the wasps came out from the nest only after the nest was kept in the plastic bag for more than 10 minutes. All six females were dissected for ovaries and spermathecae under a stereoscopic dissecting microscope. The spermathecae were removed and mounted on a glass slide in water and examined for presence or absence of sperm under a compound light microscope. All six females had nearly no fat in their metasoma, undeveloped ovaries, and empty spermathecae (= uninseminated).

\section{DISCUSSION}

\section{DisTRIBUTION}

Besides E. nigra, two Eustenogaster species, E. hauxwellii (Bingham, 1894) and E. scitula, are recorded from Viet Nam (Nguyen and Khuat, 2004; Nguyen et al., 2006). Eustenogaster hauxwellii seems to be restricted to south of the Hai Van Mountains on the border between Thua Thien Hue and Quang Nam Provinces. On the other hand, E. scitula extends its distribution northward beyond the Hai Van Mountains, with the northernmost record being from Quang Binh Province (fig. 15). Eustenogaster nigra is farther north and its southernmost record is from $\mathrm{Ha}$ Tinh Province, adjacent to Quang Binh Province. If E. nigra and E. scitula do not co-occur and if they are closely related, this segregated distribution pattern may imply speciation by a vicariance event. However, there is no distinct barrier at least currently between their distribution ranges.

\section{Nest Architecture}

The nests of Eustenogaster so far known have basically the same structure, except for 


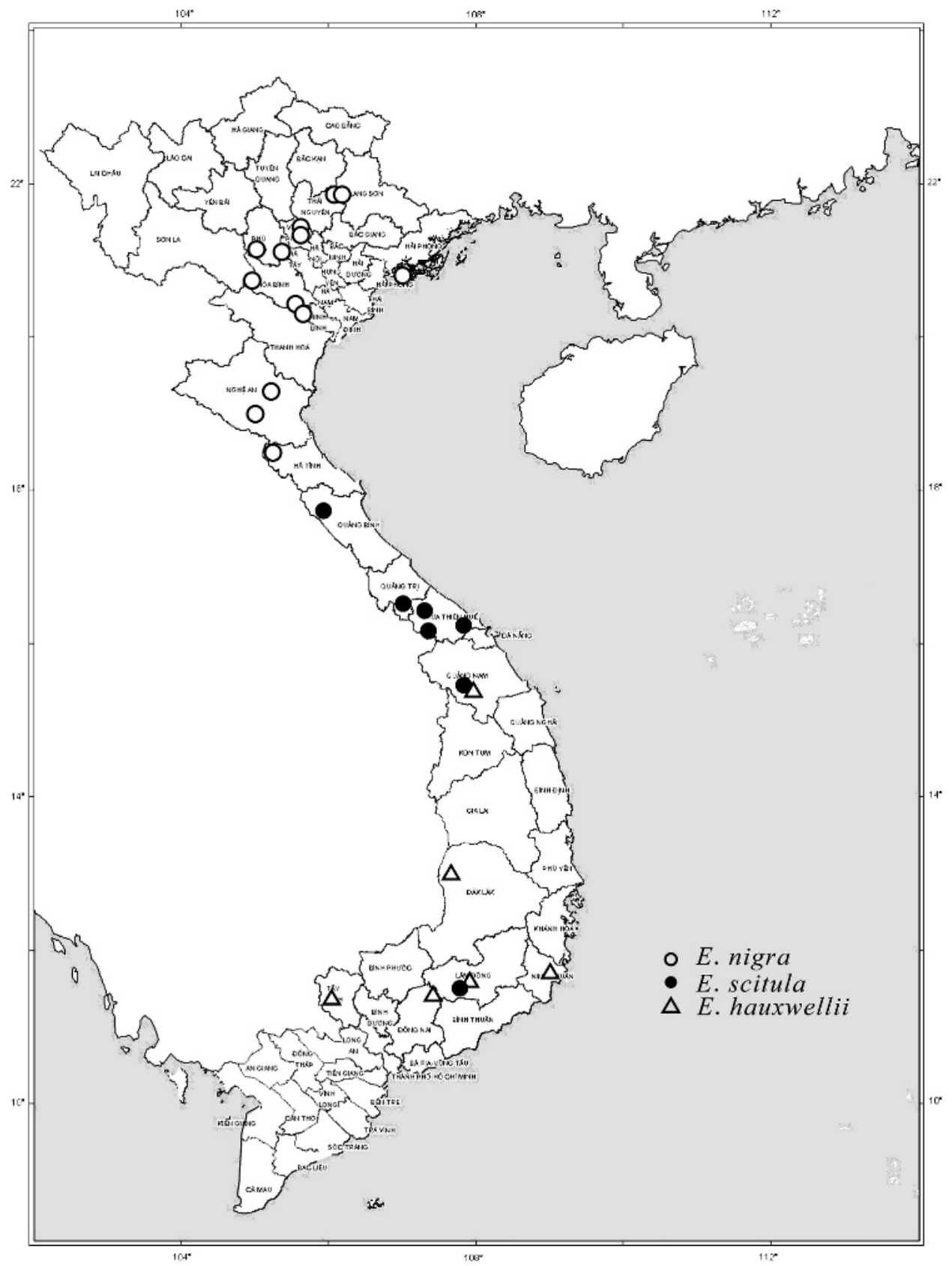

Fig. 15. Map of Viet Nam showing distribution records of Eustenogaster species.

the envelope, which can be divided into the following two types: (1) Envelope arising from the cell wall: the nest with this type of envelope is usually attached to free-hanging fibers, such as plant shoots, free-hanging roots, and thin wires. The first cell (or sometimes the few first cells) is attached by bases to the substrate and further cells are added laterally to the wall of preexisting cell(s). The envelope is made by extending 
the outer walls of the peripheral cells, and thus it forms a structure continuous to the comb. This type of envelope is often called a "pseudenvelope" (Ohgushi et al., 1983; Turillazzi, 1991), which implies that the structures are not true envelopes. Wenzel (1991: 499) disagreed with this idea, mentioning "All envelopes may have been originally derived from extensions of the cell wall." Most Eustenogaster species make nests with this type of envelope (see review by Turillazzi, 1991). (2) Envelope arising from the substrate and independent of the comb: Eustenogaster calyptodoma (Sakagami and Yoshikawa, 1968) makes nests on a horizontal or vertical flat surface, where the envelope is constructed directly on the substrate, attaching to it by the base; thus, the envelope is a structure independent of the comb. All cells are initiated directly on (= attached by their bases to) the horizontal surface (Sakagami and Yoshikawa, 1968) or the first cells are attached by their sides to a vertical substrate and further cells are added laterally (Hansell, 1987b). Ohgushi et al. (1986) described nests of Eustenogaster sp. from Sumatra, in which the envelope basically arises from the cell walls but is sometimes partially constructed directly on the substrate and is thus independent of the comb.

The two nests of E. nigra we examined have basically the structure of the first type. Among the nests of this type, the E. nigra nest most closely resembles that of $E$. fraterna (Bingham, 1987) described by Ohgushi et al. (1990) and the nest of E. eximia (Bingham, 1890) described by Krombein $(1976,1991)$ in having distinct keels and protuberances on the outer surface of the envelope and the apical end of the tubular entrance modified into bilateral extensions. The nest of E. nigra differs from that of the other two species by the entrance tube being distinctly longer (short before apical extension in the latter two species) and the keels on the outer surface of the envelope running slightly spirally (nearly straight in the latter two species). The bilateral extension at the apical end of entrance tube in E. fraterna seems to be much less developed than in $E$. nigra, whereas that of E. eximia is occasionally much elongated.

The developed earlike processes, keels on the envelope surface, meshed entrance tube, and bilaterally symmetric wings at the tip of the tubular entrance seem to increase the effect of a nest to mimic dead plant leaves. However, as discussed by Wenzel and Carpenter (1994) on "cryptic nests" in the Neotropical polistine tribe Epiponini, the evolutionary process of those traits becoming incorporated into a cryptic nest should be discussed with reference to a robust phylogeny among the taxa concerned, namely a species-level phylogeny in the case of Eustenogaster.

In the Stenogastrinae, two types of ant guard are known. One is an inverted bowl or an elongate bell made from carton (the same material as the nest) on the threadlike nest substrate at some distance from the nest, found in Metischnogaster cilipennis (Smith, 1857), M. drewseni (de Saussure, 1857), and some Parischnogaster species (reviewed by Ohgushi et al., 1990). The other is a glob of secretion from the adult's Dufour's gland (Sledge et al., 2000), also attached to the threadlike nest substrate at some distance from the nest. Such secretion ant guards are known in several species of Parischnogaster, rarely in Eustenogaster (review by Ohgushi et al., 1990; see also Carpenter, 1988), in Liostenogaster tutua Turillazzi, 1999 (Turillazzi, 1999), and possibly in Stenogaster fulgipennis Guérin-Méneville, 1831 (van der Vecht, 1975). The covering of the substrate wire with carton in nest A of E. nigra, especially the tubelike portion with the hole at midlength (fig. 13), could function as an ant guard, but it may also be that the structure absorbs rain drops running down the wire. Lack of such a covering on the substrate in nest $\mathrm{B}$ may be because the structure of the substrate, having many branches before the wasp nest, functions as an ant guard, or because the nesting site was more or less protected from rain.

The observation that nest $\mathrm{B}$ had produced adults that were still in the course of overwintering strongly suggests that E. nigra uses a nest for more than one season or more than one generation. Re-use of a nest by Eustenogaster wasps seems to be commonly practiced by succeeding on the natal nest, entering a vacant nest, or by usurpation; a female could thereby secure the place for her brood rearing with a much reduced cost 
for building (Hansell, 1987b). Re-use of a nest is not common in the social wasps, possibly because of a hygienic problem when the meconia ejected by postfeeding larvae after spinning cocoons accumulate at the bottom of a cell, possibly attracting scavenging insects or causing fungus infection. In the Stenogastrinae, however, postfeeding larvae have a behavior unique among the social wasps; that is, they pupate in a posture bending their metasoma ventrally at the junction of the first and second metasomal segments (van der Vecht, 1977; Kojima, 1990), thus allowing adult females to remove the meconia at ejection through a hole on the carton cap of the cell made by adults in Parischnogaster (Turillazzi and Pardi, 1982; Sakagami and Yamane, 1990) or possibly through a open end of a cell left uncapped in Eustenogaster.

\section{Colony Cycle}

Judging from the number of cells (15 in total, and at least 11 have very thin silk lining, indicating that they contained pupae), all adult wasps collected in nest $\mathrm{B}$ might have emerged in this nest. The mean monthly temperature in Tam Dao is about $15^{\circ} \mathrm{C}$ or lower from November to March (Nguyen et al., 2000), when the wasps should be under winter diapause. The fact that the 11 wasps collected in nest $\mathrm{B}$ consisted of 6 unmated females and 5 males indicates that they overwintered on this nest. Overwintering of unmated females together with males in a (possibly natal) nest has not previously been reported in any stenogastrine wasps or in any other social wasps.

\section{ACKNOWLEDGMENTS}

The present study was supported by the Council for Natural Science of Viet Nam for N.L.'s work, by the RONPAKU (dissertation Ph.D.) Program of the Japan Society for the Promotion of Science to N.L., and by National Science Foundation Grant 9870232 and the Center for Biodiversity and Conservation at the AMNH for collecting in Viet Nam, and partly a grant from the Japan Society for the Promotion of Science (no. 18 5900) to F.S. N.L. thanks D.L. Khuat, X.L. Truong, H.T. Ta, and V.T. Hoang for help with collecting specimens.

\section{REFERENCES}

Bell, T.R. 1936. A description of a new species of wasp assumed to belong the family Vespidae and named Paravespa eva; with remarks upon its affinities with the genus Ischnogaster and reasons for the creation of the new genus Paravespa. Journal of Bombay Natural History Society 38: 803-806, pl. 20.

Carpenter, J.M. 1982. The phylogenetic relationships and natural classification of the Vespoidea (Hymenoptera). Systematic Entomology 7: 11-38.

Carpenter, J.M. 1988. The phylogenetic system of the Stenogastrinae (Hymenoptera: Vespidae). Journal of the New York Entomological Society 96: 140-175.

Carpenter, J.M. 1991. Phylogenetic relationships and the origin of social behavior in the Vespidae. In K.G. Ross and R.W. Matthew (editors), The social biology of wasps: 7-32. Ithaca, NY: Cornell University Press.

Carpenter, J.M. 2001. New generic synonymy in Stenogastrinae (Insecta: Hymenoptera; Vespidae). Natural History Bulletin of Ibaraki University 5: 27-30.

Carpenter, J.M., and J. Kojima. "1996" [1997]. Checklist of the species in the subfamily Stenogastrinae (Hymenoptera: Vespidae). Journal of the New York Entomological Society 104: 21-36.

Francescato, E., A. Massolo, M. Landi, L. Gerace, R. Hashim, and S. Turillazzi. 2002. Colony membership, division of labor, and genetic relatedness among females of colonies of Eustenogaster fraterna (Hymenoptera, Vespidae, Stenogastrinae). Journal of Insect Behavior 15: 153-170.

Hansell, M.H. 1987a. Elements of eusociality in colonies of Eustenogaster calyptodoma (Sakagami \& Yoshikawa). Animal Behaviour 35: 131-141.

Hansell, M.H. 1987b. Nest building as a facilitating and limiting factor in the evolution of eusociality in the Hymenoptera. Oxford Surveys in Evolutionary Biology 4: 155-181.

ICZN (International Commission on Zoological Nomenclature). 1999. International code of zoological nomenclature, 4th ed. London: The International Trust for Zoological Nomenclature 1999.

Kojima, J. 1989. A new polistine species of Ropalidia (Hymenoptera, Vespidae) from 
Papua New Guinea. Japanese Journal of Entomology 57: 143-147.

Kojima, J. 1990. Immatures of hover wasps (Hymenoptera, Vespidae, Stenogastrinae). Japanese Journal of Entomology 58: 506-522.

Kojima, J. 2006. Checklist of the species of the subfamily Stenogastrinae Bequaert, 1918 (Hymenoptera: Vespidae). Available at http:// www.sci.ibaraki.ac.jp/ jkrte/wasp/steno/top.html.

Kojima, J., and J.M. Carpenter. 1997. Catalog of species in the polistine tribe Ropalidiini (Hymenoptera: Vespidae). American Museum Novitates 3199: 1-96.

Krombein, K.V. 1976. Eustenogaster, a primitive social Sinhalese wasp. Loris 13: 303-306.

Krombein, K.V. 1991. Biosystematic studies of Ceylonese wasps, XIX: Natural history notes in several families (Hymenoptera: Eumenidae, Vespidae, Pompilidae, and Crabronidae). Smithsonian Contributions to Zoology 515: $1-41$.

Nguyen, L.P.T., and L.D. Khuat. 2003. A survey of social wasps (Hymenoptera: Vespidae) in $\mathrm{Ba} \mathrm{Vi}$ and Tam Dao National Parks. In B. Nguyen and M.T. Le (editors), Problems of basic research in life sciences. Proceedings, the 2nd National Conference on Life Sciences, Hue, July 25-26, 2003: 658-661. Hanoi: Science and Technics Publishing House. [In Vietnamese with English summary]

Nguyen, L.P.T., and L.D. Khuat. 2004. Study on the social wasp family Vespidae of Vietnam and three newly recorded species of the genus Eustenogaster van der Vecht, 1969 (Hymenoptera; Vespidae: Stenogastrinae) for Vietnam. Journal of Biology [Top chi Sinh hoc] 26: 38-42. [In Vietnamese with English summary]

Nguyen, L.P.T., F. Saito, J. Kojima, and J.M. Carpenter. 2006. An annotated distributional checklist of social wasps (Hymenoptera: Vespidae) of Viet Nam. Proceedings of the First National Workshop on Ecology and Biological Resources, Hanoi, 17 May 2005: 129-137. [In Vietnamese with English summary]

Nguyen, V.K., H.T. Nguyen, L.K. Phan, and H.T. Nguyen. 2000. Bioclimatic diagrams of Vietnam. Hanoi: Vietnam National University Publishing House.

Ohgushi, R., S.F. Sakagami, and S. Yamane. 1990. Nest architecture of the stenogastrine wasps: diversity and evolution (Hymenoptera, Vespidae). A comparative review. In S.F. Sakagami, R. Ohgushi, and D.W. Roubik (editors), Natural history of social wasps and bees in equatorial Sumatra: 41-72. Sapporo: Hokkaido University Press.
Ohgushi, R., S.F. Sakagami, S. Yamane, and N.D. Abbas. 1983. Nest architecture and related notes of stenogastrine wasps in the Province of Sumatera Barat, Indonesia (Hymenoptera, Vespidae). Science Reports of Kanazawa University $28: 27-58$.

Ohgushi, R., and S. Yamane. 1983. Supplementary notes on the nest architecture and biology of some Parischnogaster species in Sumatera Barat (Hymenoptera, Vespidae). Science Reports of Kanazawa University 28: 69-78.

Ohgushi, R., S. Yamane, and N.D. Abbas. 1986. Additional description and records of stenogastrine nests collected in Sumatera Barat, Indonesia, with some biological notes (Hymenoptera, Vespidae). Kontyû 54: 1-11.

Ohgushi, R., S. Yamane, and S.F. Sakagami. 1988. Ecological distribution and habitat-linked density of colonies of stenogastrine wasps in tropical S.E. Asia. Zoological Science 5: 869-874.

Pagden, H.T. 1958. Some Malayan social wasps. Malayan Nature Journal 12: 131-148.

Sakagami, S.F., and S. Yamane. 1990. A behavior inventory of the females of two stenogastrine wasps Parischnogaster mellyi and Liostenogaster vechti (Hymenoptera, Vespidae). In S.F. Sakagami, R. Ohgushi, and D.W. Roubik (editors), Natural history of social wasps and bees in equatorial Sumatra: 73-96. Sapporo: Hokkaido University Press.

Sakagami, S.F., and K. Yoshikawa. 1968. A new ethospecies of Stenogaster wasps from Sarawak, with a comment on the value of ethological characters in animal taxonomy. Annotationes Zoologicae Japonenses 41: 77-84.

Schulthess, A. von. 1927. Fauna Sumatrensis. Vespidae (Hym). Supplementa Entomologica 16: 81-92.

Sledge, M.F., A. Fortunato, S. Turillazzi, E. Francescato, R. Hashim, G. Monetim, and G.R. Jones. 2000. Use of Dufour's gland secretion in nest defence and brood nutrition by hover wasps (Hymenoptera Stenogastrinae). Journal of Insect Physiology 46: 753-761.

Turillazzi, S. 1988. Adults and nest of Liostenogaster vechti n.sp. (Hymenoptera Stenogastrinae). Tropical Zoology 1: 193-201.

Turillazzi, S. 1991. The Stenogastrinae. In K.G. Ross and R.W. Matthew (editors), The social biology of wasps: 74-98. Ithaca, NY: Cornell University Press.

Turillazzi, S. 1999. New species of Liostenogaster van der Vecht 1969, with keys to adults and nests (Hymenoptera Vespidae Stenogastrinae). Tropical Zoology 12: 335-358.

Turillazzi, S., and S. Carfi. 1996. Adults and nest of Liostenogaster pardii n.sp. (Hymenoptera Stenogastrinae). Tropical Zoology 9: 19-30. 
Turillazzi, S., and L. Pardi. 1982. Social Behavior of Parischnogaster nigricans serrei (Hymenoptera: Vespoidea) in Java. Annals of the Entomological Society of America 75: 657664.

Vecht, J. van der. 1975. A review of the genus Stenogaster Guérin (Hymenoptera: Vespoidea). Journal of the Australian Entomological Society $14: 283-308$.

Vecht, J. van der. 1977. Studies of Oriental Stenogastrinae (Hymenoptera Vespoidea). Tijdschrift voor Entomologie 120: 5575.

Wenzel, J.W. 1991. Evolution of nest architecture. In K.G. Ross and R.W. Matthew (editors), The social biology of wasps: 480-519. Ithaca, NY: Cornell University Press.
Wenzel, J.W., and J.M. Carpenter. 1994. Comparing methods: adaptive traits and test of adaptation. In P. Eggleton and R. VaneWright (editors), Phylogenetics and ecology: 79-101. London: Academic Press.

Williams, F.X. 1919. Descriptions of new species and life history studies. Report of work of the Experiment Station of the Hawaiian Sugar Planters Association, Entomological Series Philippine Wasp Studies 14: 18-186.

Yoshikawa, K., R. Ohgushi, and S.F. Sakagami. 1969. Preliminary report on entomology of the Osaka City University 5th Scientific Expedition to Southeast Asia 1966 - with descriptions of two new genera of stenogastrinae wasps by $\mathbf{J}$. van der Vecht. Nature and Life in Southeast Asia 6: 153-182. 
Complete lists of all issues of the Novitates and the Bulletin are available at World Wide Web site http://library.amnh.org/pubs. Inquire about ordering printed copies via e-mail from scipubs@amnh.org or via standard mail from: American Museum of Natural History, Library-Scientific Publications, Central Park West at 79th St., New York, NY 10024. TEL: (212) 769-5545. FAX: (212) 769-5009. 